\title{
The myth and the reality of energy recovery from municipal solid waste
}

\author{
S A Abbasi®
}

\begin{abstract}
Background: Any manner of development can be sustainable only if the waste generated by it is not allowed to accumulate but is fully reused/recycled/recovered. Among the strategies to attain this goal have been the attempts to recover energy from municipal solid waste (MSW). About $60 \%$ of MSW is carbonaceous, consisting of materials which can either be biodegraded into fuels like methane or incinerated, thereby generating utilizable energy. MSW also contains several components - like metallic scrap and glass pieces-which can be reused or recycled, thereby achieving energy conservation. Given these attributes, MSW appears to be a potential source of energy and resources. Indeed, this belief that MSW is usable if only we try sincerely enough to do so prompts most of us to keep generating much more MSW than is warranted. But how realizable really is the energy potential of MSW? What perils loom into view when we actually set out to utilize MSW as an energy source? The present study addresses these crucially important questions.

Methods: The work is based on a critical content analysis of the prior art.

Results: The generation of MSW has consistently outpaced the world's efforts to dispose of it cleanly, and the energy (and material) recovery from MSW is easier said than done. In most instances, what is technically feasible is economically unfeasible. And what is economically feasible-such as setting the waste on fire as is often done in developing countries-is exceedingly harmful to the environment and the human health. Measures such as sanitary landfilling and incineration create as many new problems as the old ones they solve. Moreover, despite the use of these less-than-adequate technologies, a major portion of MSW generated in the world lies untreated.

Conclusions: As the MSW output is expected to double by 2025, this situation is only set to become worse. Rising tides of E-waste would compound the problem even further. Hence, enormous stress should be put on the reduction of MSW generation by controlling wanton consumerism and wastage, rather than continuing with it in the false hope that technology will soon provide a magical solution and eliminate the problem.
\end{abstract}

Keywords: Municipal solid waste, Landfills, Incineration, Anaerobic digestion, Composting, Biogas

\section{Background}

\section{The municipal solid waste problem}

Municipal solid waste (MSW) is the name given to the assorted, basically non-hazardous, biodegradable/nonbiodegradable, carbonaceous/non-carbonaceous, and reusable/unusable solid waste that we generate in the course of day-to-day living and regulatory/commercial activities. Solid wastes from households, commerce, trade, office buildings, and the yard, garden and street sweepings come under the gamut of MSW $[58,136]$.

Correspondence: abbasi.cpee@gmail.com

Centre for Pollution Control and Environmental Engineering, Pondicherry University, Chinnakalapet, Puducherry 605 014, India
Construction and demolition debris, sewage sludges, industrial process waste, hazardous hospital waste etc. are excluded [176].

Even though MSW is generated wherever human beings dwell, its quantity and complexity are much higher in urban and suburban situations compared to rural ones $[22,26,29,98]$. With very rapidly increasing rate of urbanization all over the world and the rapidly growing globalization-fuelled consumerism, urban solid waste generation in developing economies like India and China is rising steeply [51, 59, 124, 163]. Even the periodic spells of economic slowdown, or fall in the rate of population growth, do not seem to reduce the increasing rate

(c) The Author(s). 2018 Open Access This article is distributed under the terms of the Creative Commons Attribution 4.0 International License (http://creativecommons.org/licenses/by/4.0/), which permits unrestricted use, distribution, and reproduction in any medium, provided you give appropriate credit to the original author(s) and the source, provide a link to the Creative Commons license, and indicate if changes were made. 
of MSW generation in developing countries. For example, despite a $3.8 \%$ decrease in economic activity and only $0.8 \%$ population growth that occurred in 2015 in Brazil, the total quantity of MSW generated there increased by $1.7 \%$ [21]. In terms of their present per capita MSW generation, these countries may be way behind the developed ones (Fig. 1), but due to their much larger populations, the country-wise MSW production there is approaching that of the developed countries. For example, China and India have become the world's second and the seventh biggest MSW producers [182, 197]. The Russian Federation, Brazil and Mexico are also among the world's top 10 biggest MSW-generating countries (Fig. 2). Moreover, of the world's 15 most populous countries, 13 belong to the developing world and 9 of these have population densities 2 times (Mexico) to 36 times (Bangladesh) greater than that of the USA. The two most populous countries of the world-India and China-with their combined population approaching three billion have population densities 13 times and 4 times greater than that of the USA, respectively. All these countries have a lot less land mass, per head, available to assimilate MSW than the USA and several other less densely populated countries. For this reason, and also lack of resources to manage MSW, the problem of MSW disposal is fast acquiring catastrophic proportions in several countries [27, 96, 134]. It is common to see solid waste dumped at street corners, roadside and water-bodies even in relatively much cleaner and well-managed cities like Puducherry, India [2] (Figs. 3 and 4). During the last two decades, there has been exponential growth in another form of solid waste-the electrical and electronic equipment (EEE) waste, or E-waste-which is often dumped along with MSW or sent to MSW landfills [72, 146, 188]. In another 13 years, the world's MSW output is expected to double from its present 1.3 billion tons to 2.6 billion tons [26, 197]. The quantities of E-waste are also expected to multiply in the coming years [145, 147] which will put much greater stress on the governments and the people who are unable to cleanly dispose of most of even what is being presently generated.

It was in the early 1970s that the problem of MSW disposal had begun to look daunting as urbanization began its runaway growth [5]. From then onwards, extensive R\&D efforts have been made to find ways and means of gainfully utilizing MSW $[6-8,17,23,35,36,141,163$, 164]. Till now, these efforts have not fructified in most regions of the world beyond occasional success stories of a village here or a neighborhood there managing to assimilate their MSW within their premises [200]. For example, the extent of MSW that is recycled in Malaysia is a mere 5\% [17] even though Malaysia is regarded as among the most advanced of developing nations. But vigorous efforts are continuing to be made even as the problem is actually increasing in magnitude and complexity rather than getting even partially solved $[15,22,98$, $103,166,196]$. The focus in recent years has been on generating energy from MSW, besides material recovery $[16$, $20,63,113,200,204]$. The hope that a 'clean and sustainable solution to the MSW problem (and the E-waste problem)' is around the corner continues to be expressed [116, $175,186]$. What are the odds that these hopes will be realized? This paper attempts to answer this question.

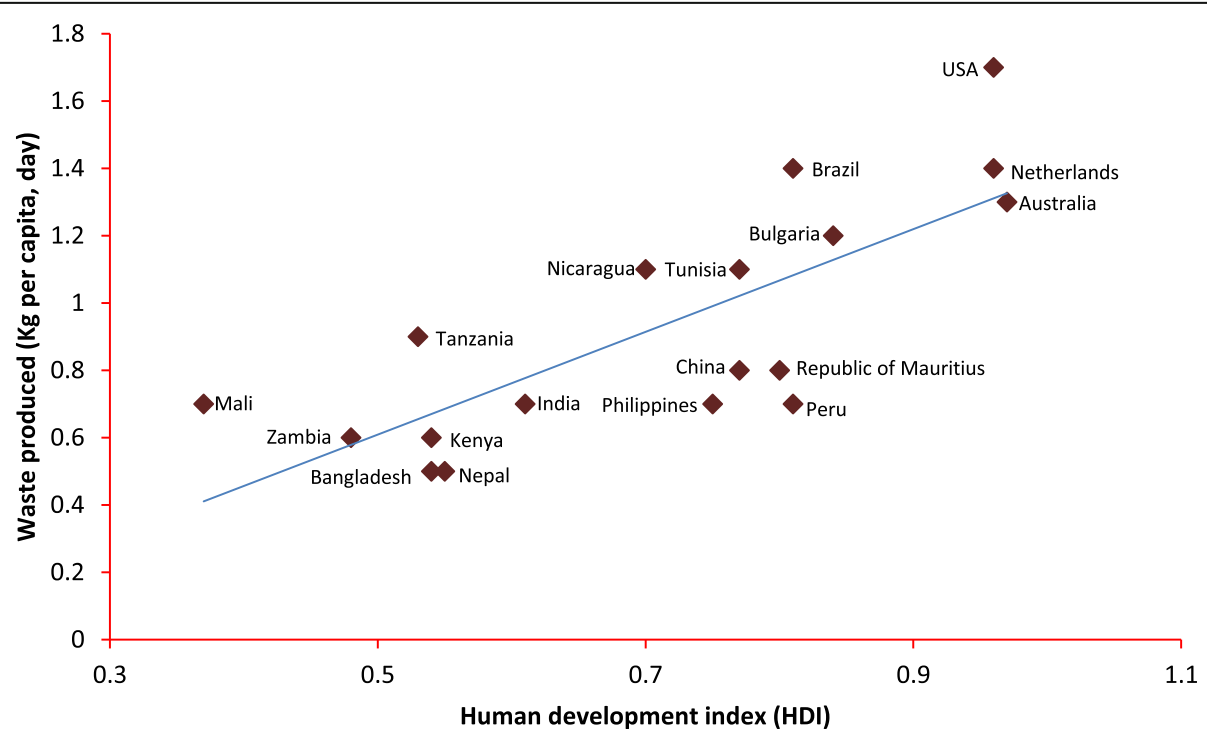

Fig. 1 Relationship of prosperity, as reflected from human development index (UNDP, 2009), and per capita waste generation. Based on representative data of major cities of 18 countries as reported in UN-HABITAT [180] 


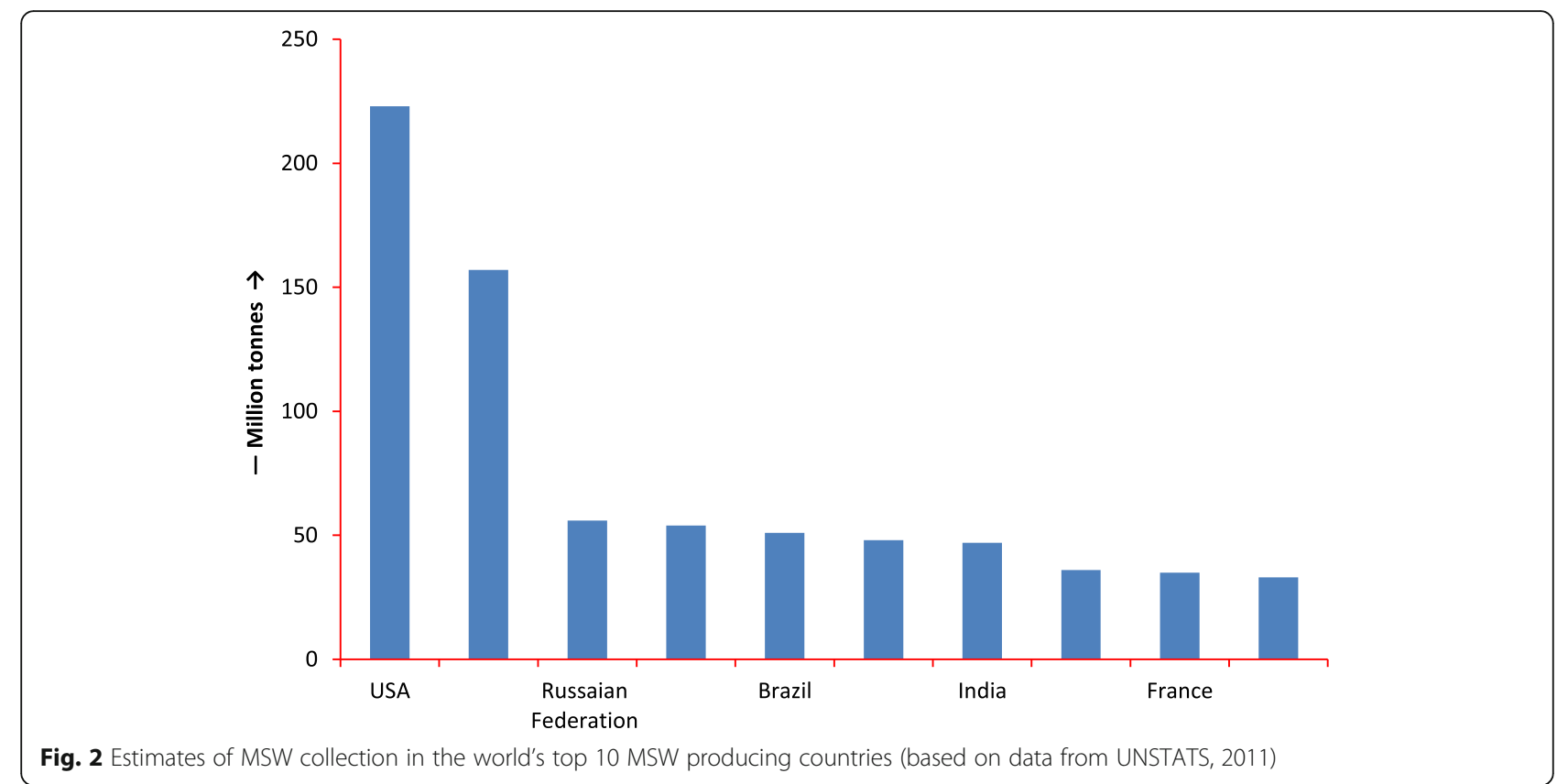

\section{MSW as an energy source}

Urban waste is made up of an assortment of materials, not all of which are reusable, but most are [35, 42, 40, $61,138,193]$. Due to the very large, and rising, quantities in which urban waste is generated all over the world $[42,47,96,101,136,164]$ and the fact that over half of it is biodegradable [2, 149, 150, 163, 191], it is considered as a large reservoir of renewable energy [29, 32, 38, 51, 95]. Indeed as is true for other non-conventional energy sources, the energy that can be, theoretically, derived from MSW is enormous [71, $102,120,203,194]$. Also, considering that MSW is not only 'free', but entails expenditure in transportation and disposal, any prospect of deriving energy from it appears a great blessing. But, as has almost always been happening with

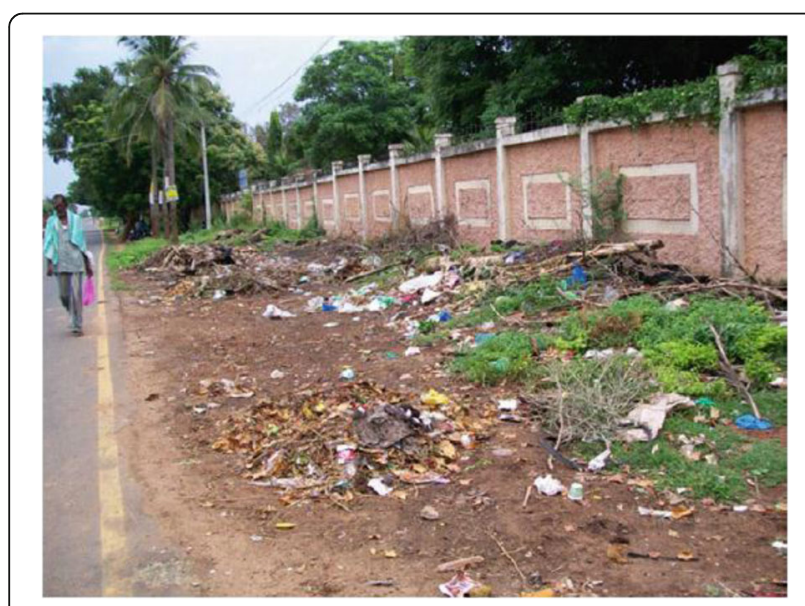

Fig. 3 Indiscriminate dumping of solid waste (Puducherry, India) other non-conventional energy sources $[2,8-11]$, the picture soon begins to lose its sheen as environmental impacts of different forms and magnitudes begin to show up.

\section{Prospective energy saving by material recovery from MSW}

Even before any attempt is made to generate energy from MSW, some energy can be indirectly gained from it in the form of usable materials [188]. Material recovery achieves energy saving; for example, production of aluminum is an extremely energy-intensive process, but recycling aluminum requires just one tenth as much energy as producing it from bauxite $[144,179]$. Recycling of other common metals is also

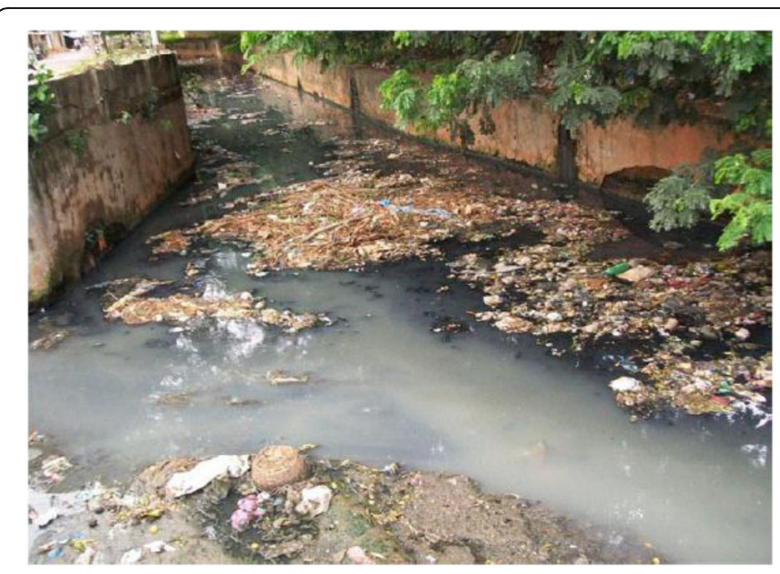

Fig. 4 Solid waste dumped in a canal (Puducherry, India) 
believed to cost much less energy than their ab initio production (Table 1). For precious metals like silver and gold contained in waste computers, material recovery is even more energy-saving [76]. These attributes always make material recovery an enchanting prospect. But, on the ground, the prospect is hardly put to practice. The main reason is that the revenues generated from waste recyclables are not able to offset the cost of collecting, sorting and transporting of waste [128]. What appears profitable on paper when seen out of context of hidden costs ceases to be so when actually attempted. A good deal of valuables are being illegally recovered from E-waste by informal, unscientific, and labour-intensive recycling methods in developing countries, but it is leading to such gross pollution of the environment and is posing such grave risk of serious diseases that the cost of it all will, in the long run, likely to be several times higher than the short-term material gains [45, 75, 146, 174, 178, 179]. Moreover, the presence of brominated fire retardants (BFRs) in the non-metallic components of E-waste makes the recycling of those components exceedingly difficult [194].

It is pertinent to report that South Korea recycles $58.1 \%$ of its MSW [141], topping the list of the Organization for Economic Cooperation and Development (OECD) countries in this respect. The countries next to South Korea on this count are Germany and Belgium who recycle $47.6 \%$ and $33.8 \%$ of their MSW, respectively, while the average OECD MSW recycling rate is only $25 \%$ [137]. Even this extent of success has been achieved because these countries implement 'volume-based waste fee' (VWF) system or charge 'pay-as-you-throw' (PYT) fee. In this paradigm, the cost of recycling items like plastic bags are added upfront to their sale prices, and the revenue thus earned is utilized in recycling the same items after they have been discarded. Seen from this perspective, VWF and PYT are effective forms of taxes that are levied on certain items to obtain the cost of recycling those items after they had turn to waste. In this respect, VWF and PYT are

Table 1 Estimates of energy saved when a material is recovered from waste in comparison to its ab initio production ([179])

\begin{tabular}{ll}
\hline Material & Energy savings (\%) \\
\hline Aluminum & 90 \\
Copper & 85 \\
Iron and steel & 74 \\
Lead & 65 \\
Zinc & 60 \\
Paper & 64 \\
Plastic & $>80$ \\
\hline
\end{tabular}

similar to the concept of 'extended producer responsibility' that is invoked in case of computers and other information technology gadgets in developed countries due to which the cost of recycling is added to the selling price. But whereas these schemes have achieved some success in South Korea and the developed countries, it has not been possible to implement them in India and other developing countries [147]. This is because political compulsions make the governments disinclined to charge what will be perceived as an extra tax. There are also difficulties in the implementation of such measures because even most of the environmental protection laws have been subject to more breech than compliance $[1,12]$.

Interestingly the state of New Jersey in the USA, which was the first state to make recycling mandatory (in 1987) and which led other states in terms of recycling the highest fraction of MSW (44.5\%) for several years thereafter, has fallen back in recent years [1]. This has occurred due to the absence of state or local aid to finance recycling programmes and the drop in the cost of waste removal. Similar situations exist in most parts of India, and indeed, many other regions of the world, which are limiting the utility of recycling as a means of energy conservation in the present-day economic paradigm. For example, Queensland, which is the second largest state in Australia, recycles only about $5 \%$ of the waste it produces [49]. In India, rag-pickers eke out a subsistence living by sifting through mounds of waste but at great risk to their health $[27,53,160]$. Quite often, to facilitate picking of metallic scrap, the mounds of waste are set on fire $[2,12,22,98]$. This is not only a highly eco-degrading and unhygienic practice but achieves only very little recycling at very high environmental costs.

If assessment is done of the net energy gains from the recovery of various materials and incentives given to recycling the wastes that are of more value when recycled than incinerated, the situation may change for the better. But, as of now, there is no such move on the horizon. The political and economic viability of such a move, even if it gets made, is low because providing 'incentives' indirectly means providing subsidies at taxpayer's cost. All in all, a state of near saturation seems to have been reached as far as limits to economically reuse MSW is concerned. Whatever little is easily retrievable is retrieved. One can say that new technology may emerge to find more remunerative uses of MSW, but such prospects are dim because several decades of intensive research all over the world has brought forth processes which are technically feasible but too costly to implement. Unless the present benefit-cost equations change in favour of MSW reuse, which are not likely in foreseeable future, 
there may be no further gains in energy saving through this option-certainly not substantial enough to make a difference.

\section{Energy recovery by incineration}

The most prevalent method of generating energy from urban waste continues to be incineration. Incineration has the advantage of greatly diminishing solid waste quantities (up to 70\%) and volumes (up to 90\%) for landfill and killing pathogens [41, 203]. Depending on their location, incineration plants may also reduce the distance that municipal wastes have to be hauled. But these advantages are offset by emissions of carbon oxides, sulfur oxides, particulates, heavy metals and other pollutants from the incinerators. For each tonne of MSW that is incinerated, $15-40 \mathrm{~kg}$ of hazardous waste is produced, requiring further treatment $[83,85,96$, $114,118,139,195]$. Particular attention has been focused on the emissions of dioxins and furans [43, 44, $112,130,205,206]$, which are more toxic and costlier to control than other pollutants. Indeed, waste incineration is regarded as one of the greatest contributors to the release of dioxins into the environment $[126,207]$.

As is true for any and every form of pollution, it is, theoretically, possible to control the pollution generated by incinerators as well. Some of the economically developed countries have been able to achieve relatively 'clean' incineration of MSW by implementing very rigorous pollution control measures, typified by Austria [73, 148, 196, 197]. But in practice, it gets more and more expensive to do so for every incremental improvement in the level of treatment. As the volumes of waste to be handled increase, the number of players managing the incinerators increases, profit margins shrink and departures from 'best practice' become more and more frequent $[106,114,119,196]$.

In developing countries like India, implementation of pollution control regulations is far from rigorous [1, 9, $12,158,160]$. It is not uncommon to find companies which install pollution control systems with incinerators (to get the mandatory licence) but then save upon costs of operation and maintenance by not operating such systems properly-often not at all. Elsewhere in the world, too, polluters tend to save the cost of pollution control in one unethical way or the other [119]. We have before us the example of E-waste. By introducing legislation based on 'extended producer responsibility' (EPR) paradigm, which in turn follows the principle of life-cyclebased environmental management, the European Union and other developed countries have made E-waste disposal cleaner than it was $[145,146]$. But this has also made the disposal much more expensive than it was. The result is that huge volumes of E-waste from these countries are illegally exported to China, India, Africa and other developing countries where they grossly toxify the environment $[145,146]$. In a way, EPR has prompted developed countries to 'sweep some of their dirt' to the backyards of other countries. On their part, developing countries are well aware of the problem but are unable to contain it because, to the crafty middlemen and the impoverished multitudes who, together, sustain the illegal trade and recycling of E-waste, the immediate economic gains are too compelling to worry about long-term environmental losses [146].

Incineration leads to emissions of metals like mercury [108] and organics like dioxins $[18,84,109,166]$ which are highly toxic. They not only put the people living in the vicinity of incinerators to great risk $[28,110]$ but also cause dispersion of these pollutants far and wide [54]. Elevated levels of these pollutants and their adverse effect on human health are being reported with increasing frequency $[107,112,156,162,189,208]$.

Incineration is also known to increase the lability of toxic metals which, otherwise, would have remained contained in polymeric matrices. In this manner, incineration can actually enhance the damage potential of some of the MSW even as it reduces its quantity $[86,146]$. Concern has been mounting over the disposal of the ash residues from incinerators, more so because the content of toxic elements-cadmium, mercury, arsenic and others-in MSW is increasing due to the contribution from discarded E-waste, batteries, lighting fixtures and other sources [68, 112, 193, 206]. Ecotoxicological studies on leachates obtained from ashes produced by urban waste incinerators in EU countries have prompted calls for more stringent regulations for ashes disposal and use [187].

At some quarters, biosolid combustion is still spoken of as a 'green energy source' [165, 192, 202] and 'beneficial to environment' [127], but the broader consensus is that even as incineration does not always produce more energy than it utilizes, it almost always does prove to be a major environmental stressor. Every single effort of the government in India to set up MSW incineration plants-often euphemistically called waste-to-energy plants-is being met with stiff opposition from the people [27, 129].On the one hand, such plants are a source of enormous pollution and, on the other hand, generate energy which is about twice as costly as the energy available from the grid, even after budgeting for the clean development mechanism $(\mathrm{CDM})$ credits. It is no wonder, then, that the three waste-to-energy plants that were set up near three major MSW dump sites in Delhi are almost idle [27]. Elsewhere, the waste-to-energy plants that have been set up by the Indian government in partnership with private players have been heavily subsidizednone is commercially viable [134]. 
Worse still, once incinerators have been installed, the compulsion to utilize their capacity to the full can (and does) result in a tendency to increase the waste stream through the curtailment of recycling, a situation wherein, effectively, more energy is wasted than is produced. It can be said that widespread reliance on incineration as a solid waste management option may turn out to be 'a remedy worse than the disease'.

\section{Capture and utilization of landfill gas}

As per the information currently projected by the United Nations Statistics Division [182], which is based on the data pertaining to 2009 provided by 52 of the developing countries, these countries were generating 368 million tonnes of MSW. But the list does not include some of the world's largest countriesIndia, Brazil, Indonesia, Malaysia, etc.-and can be at best considered broadly indicative. As per this data, about three fourths of all the MSW is 'landfilled' in developing countries. But except in China, where about half the MSW is put in sanitary landfills, most of the MSW in other developing countries-including India which is among the most technologically advanced of developing countries-is just dumped on public (government-owned) land [70, 158, 181, 198]. It is erroneously called 'landfilling' because no compacting, sealing, leachate collection or methane capture is exercised [22, 27, 51, 70, 98, 157, 198]. Even in Delhi-which is the capital of India and from where most of the scientific and technological research in India is coordinated-the MSW is simply piled up on land. The biggest of such dump sites, at Bhalaswa, has by now risen to a height of $55 \mathrm{~m}$, with no possibility of it being closed from further dumping in the foreseeable future. This fact has made the Supreme Court of India sarcastically remark that the landfill site 'will one day touch the height of Qutub Minar and red beacon light will have to be used to ward off the aircraft' [27]. Ever so often these mountain-size piles tend to collapse under their own weight. The most recent such collapse, at the Ghazipur dump site, killed two people [27]. With India now producing over 55 million metric tonnes of MSW per year of which a mere $22 \%$ is treated and disposed of [134], the heights of the waste dumps are only going to increase across India. The toppling of such dumps can spell disaster-at least 39 people died, 11 houses destroyed and sewage was dammed by waste when a MSW dump toppled in Istanbul in 1993 [99]. Similar collapses of MSW mounds in Quezon City, Philippines, in 2000 and in Bandung, Indonesia, in 2005 resulted in 278 and 147 confirmed deaths, respectively.

Among developed countries, Canada, the USA, Ireland, Portugal, Iceland, Australia, New Zealand, Israel, Qatar and Spain send more than $50 \%$ of their MSW to landfills, closely followed by Italy (49.2\%), the UK (49.1\%) and Finland (46.1\%). The USA, which has the highest per capita MSW generation in the world, adds to about 205 million metric tonnes of MSW per annum and sends $63 \%$ of it to landfills [45]. These figures indicate that the reliance of the world on sanitary landfills is not only very high; it is likely to increase in the future as India and other developing countries may try to move from waste dumps to sanitary landfills $[22,98,157]$.

Hence, despite the by now well-documented problems of foul-smelling and toxic gas emissions, water and soil pollution caused by the leachate, explosion and fire hazards, and contribution to global warming, $[82,97]$ landfills will continue to be used widely for urban waste disposal for want of a better option [14, $24,48,62,107,115,132]$. No other solid waste management technology can handle substances of such varied characteristics as sanitary landfills can nor is any other technology as inexpensive, for each tonne of assorted waste handled, as sanitary landfills. Indeed, for many countries like India, who are hard put to bear the costs of even sanitary landfills, the possibility of using more expensive 'cleaner' technologies of MSW management is very remote.

In a landfill, the compacted waste initially undergoes aerobic decomposition [43, 74, 123], but the oxygen is soon depleted and anaerobic degradation sets in [4, 124]. The resulting emissions typically contain about $55 \%$ methane $\left(\mathrm{CH}_{4}\right)$ and about $45 \%$ carbon dioxide $\left(\mathrm{CO}_{2}\right)$. Both are global warming gases, of which the former has, molecule to molecule, 25 times more global warming potential (GWP) than the latter [3]. By some estimates, $\mathrm{CH}_{4}$ has 34 times greater GWP than $\mathrm{CO}_{2}$ [159]. Several measurements at simulated lab-scale landfills and also at full-scale existing landfills have indicated that landfills may also be emitting nitrous oxide $\left(\mathrm{N}_{2} \mathrm{O}\right)$. Given that $\mathrm{N}_{2} \mathrm{O}$ has 300 times greater GWP than $\mathrm{CO}_{2}$, this is a possibility of great concern [94]. But of equally serious concern are the emissions of highly toxic inorganics and organic compounds that occur in the landfill gas (LFG), of which several are also ozone-depleting substaces $[83,86]$. These include mercury vapour $[199,171]$, highly toxic per- and polyfluoroalkyl substances [131], other toxic volatile organics [130] and malodorous hydrogen sulfide and mercaptans $[55,100]$. Dioxins have also been recorded among the LFG emissions [111, 155]; their levels shoot up to several thousand times higher if some part of the landfill contents happens to catch fire $[60,130]$. It has also been found that brominated flame retardants-which are common in landfills-can undergo photolytic degradation on the landfill surface to generate dioxin-like compounds [167, 168]. But if the toxic and odorous LFG is 
aesthetically offensive and hazardous to plants and animals, it pales into insignificance in comparison to the lethal cocktail of chemicals that a typical landfill leachate is. Thick with toxic levels of metals and metalloids, harmful organics including dioxins and pathogenic microorganisms, the leachates play havoc with the soil, water and biota which come in their contact $[69,78,89$, 109]. Even small quantities of landfill leachate are capable of causing serious damage to surface and groundwater receptors [13]. In recent years, a new class of pollutants has entered landfill leachates-engineered nanomaterials [142]. In what manner and to what extent they can harm biota is largely unknown.

Whereas sanitary landfills have been monitored for the quality of their LFG and leachate, no such assessment exists of the emissions that come from the mountains of garbage which are rising in India and elsewhere due to the dumping of MSW. Ever so often fires break out in these piles due to the emitting methane getting auto-ignited. Equally often, rag-pickers set the MSW on fire to make picking of metallic components easy. In peri-urban areas and villages where there is no organized MSW collection, it is common for the inhabitants to heap up the strewn MSW and set it on fire. In all such instances, copious amounts of dioxin and other toxic gases must be getting released, but of which no account exists. There are a few reports on toxic emissions but only with reference to E-waste dumps [39]. In the like manner, the leachate coming out of the waste dumps must be severely polluting the soil and water, but there is no documentation of it, let alone any measures to combat it being in place $[12,27,134]$.

About $0.35 \mathrm{Nm}^{3}$ of landfill gas (LFG) - also called 'biogas'-is generated per kilogram of solid waste, representing a substantial source of energy. For long, the cost of recovering, cleaning and using LFG had worked out higher than the cost of equivalent amounts of fossil fuel energy except at a few locations. Due to this, the LFG was either simply allowed to escape or was flared off $[2,184]$. But in recent years, LFG has been recognized as a major contributor to the global GHG emissions-for example, it is estimated to contribute as much as $12 \%$ of the global methane emissions $[184,185]$. This has prompted efforts to capture and use LFG as a fuel $[122,183,184,186]$. This route still leads to $\mathrm{CO}_{2}$ emissions, but the GWP of LFG gets substantially lowered due to the conversion of methane into the much lesser global warming $\mathrm{CO}_{2}$ [3].

As of now, there are 632 operational LFG energy projects in the USA [184], in which methane from $26 \%$ of the landfills in the USA is being captured for energy recovery. The utilization of LFG in Germany and elsewhere in Western Europe is even better [57, 135, 153, 154]. The European Union has passed regulations to enforce effective management of LFG [135, 201], and developing countries are also trying to catch-up [17, 19, $100,104,200,204]$. But the fact remains that under the best of circumstances, not more than $90 \%$ of LFG can be captured; the success rate in this respect is generally closer to $60 \%$, and very substantial quantities of methane continue to escape. For example, despite vigorous implementation of LFG capture programmes in Germany which reduced GHG emissions to approximately two thirds, as much as 60,000 to $135,000 \mathrm{t} \mathrm{CO}_{2}$ equivalent of LFG is still being emitted annually [81, 153]. Secondly, the duration up to which a landfill emits biogas at a rate adequately high for recovery at bearable costs is 7 to 10 years $[88,126,190]$. Subsequently, the gas flux dwindles to make recovery prohibitively uneconomical even as the gas continues to emerge for several decades thereafter.

Thus, after a landfill has attained a certain age its biogas emissions become too lean to make capture practicable yet are significant enough to contribute to global warming and other forms of pollution. Attempts such as in situ aeration to shift the waste degradation process from anaerobic to aerobic-so that it generates $\mathrm{CO}_{2}$ instead of methane $[79,153]$-are being made. But they will only add to the cost of the landfill maintenance.

Much of what happens in a conventional sanitary landfill cannot be controlled or doctored because a conventional sanitary landfill is essentially alternative layers of soil and MSW which have been compacted. This realization had led to the concept of 'bioreactor landfills', which was introduced in the late 1970s [80, 143]. The concept envisages to turn conventional sanitary landfills into rigorously controlled 'bioreactors'. For example if the MSW can be pre-processed in terms of separating the non-biodegradables, then shredding the biodegradable part, and if the leachate is recirculated-after some pre-treatment- it may enhance the rate of biodegradation occurring in the landfill. This can, in turn, make the landfill more space-efficient and 'clean'. Provision can also be made for steps such as ozonation of stabilized waste. To achieve all these, appropriate controls of temperature, moisture, $\mathrm{pH}$ and nutrients-factors which most strongly effect the rate of biodegradation in a landfill-can be put in place.

During the last two decades, substantial efforts have been invested in developing the bioreactor landfill technology $[13,30,65,66,80,81,87,80,91-93,118,140$, $153,152,172,196]$. But very few full-scale landfill bioreactors are currently in operation, of which none exists in any developing country $[12,80,81,170]$. The reasons are not hard to see; every step to turn a conventional landfill into a bioreactor requires capital and recurring expenditure. The more controlled-hence efficient-a bioreactor landfill is, the costlier will be its commissioning 
and operation. When a large part of the world is unable to afford even conventional sanitary landfills, there is a little possibility that it will be able to set up bioreactor landfills.

Independent of the bioreactor concept, extensive research is also being done on the treatment of landfill leachate [34, 77, 117, 133, 161, 198]. But in this case, too, better the extent of treatment, higher is the cost. As a result, much of the leachate is either not treated at all—as in India [27, 134] —or is given only 'affordable' treatment which leaves much of its toxicity unaddressed. The constraint in leachate treatment-as it indeed is in most problems of pollution control being faced by the world-is not the technology but the costs [12].

There are also risks associated with the failure of landfill liners/covers and leachate dams. In one instance, this type of failure, which occurred at Quezon City, Philippines, in 2000 led to as many as 278 confirmed deaths, besides over 80 people missing who were presumed dead [31, 121]. Considering that there are also risks of fire, explosion and pollution [105, 125], the gain of energy recovery from landfills can at best be viewed as 'achieving some good from a bad bargain'. It may reduce GHG emissions linked to urban waste disposal but will not eliminate them. Moreover, if the quantities of urban waste generation continue to rise, especially in the economically advancing countries as is reflected clearly in the trends $[2,26]$, the advantage would soon be offset by the additional emissions. Given this context, the hope expressed by some authors that 'sustainable' bio-plastic can be produced using landfill-derived methane [46, 201] or 'renewable energy assets' can be developed by harvesting solar energy falling on landfills [90] appears rather unrealistic. In Europe alone, an estimated 5.25 billion tonnes of MSW has been landfilled between 1995 and 2015, of which plastic is estimated to have contributed over a billion tonnes [37]. Possibilities of excavating and recycling this plastic have been assessed and found unattractive because of the high level of ash, heavy metals and other impurities now embedded in it [37].

\section{Anaerobic digestion of MSW}

Another route by which energy can be generated from MSW is by anaerobic digestion (AD) of some of its biodegradable component. Efforts are being made to bring in larger fractions of MSW within the preview of $\mathrm{AD}$, enhance the $\mathrm{AD}$ process efficiency and improve its presently negative energy balance $[2,25,50,52,56,71,126$, 151, 169, 177].

Anaerobic digestion has been a hugely successful option for treating liquid wastes carrying high chemical oxygen demand (COD) [2, 172] and animal manure [173]. Compared to aerobic processes, anaerobic processes need less energy to operate. They also generate energy in the form of methane-rich biogas, and it is possible to run anaerobic digesters in a manner that they become 'energy positive'-in other words, yield more energy than they consume $[33,71]$.

But serious operational problems are encountered when MSW or other biodegradable solid waste (such as leaf litter, weeds, vegetable and fruit peels, food waste) is to be processed by anaerobic digestion [7, 64, 67]. Feeding such a waste and ensuring its digestion and the movement of the digested product out of the reactor are all besieged with problems because, unlike liquid waste which can be easily homogenated and which moves through reactors easily, solid waste creates major difficulties in mass transport [7]. This necessitates a lot of pre-processing, pre-treatment and also post-digestion processing which all add to the cost of the system $[2,152,178]$.

Developing countries, including the world's two most populous countries-China and India-extensively use 'biogas plants' which are essentially 'low-rate' anaerobic digesters suitable for processing animal manure [173]. These and other developing countries also use 'high-rate' anaerobic digesters for treating high-COD wastewaters such as distillery and food industry wastewaters [2, 3]. But none of these countries can afford anaerobic digestion of MSW because of the much higher costs involved. AD is being utilized only in some of the developed countries, especially of Western Europe [50] due to these attributes:

1. Because anaerobic digesters are enclosed systems, they allow all of the biogas to be collected, unlike the landfill biogas of which only $30-40 \%$ is usually captured, if at all. Even at the best of times, a maximum of $60 \%$ of landfill biogas is retrievable.

2. An end product that can be used as a soil conditioner is produced. By mixing the refuse with animal dung, the system efficiency can be improved, allowing for a more simple process design, thereby improving the economic viability of the system. This is due to the better $\mathrm{C}: \mathrm{N}$ ratio that is achieved if MSW is mixed with dung.

3. By diverting easily digestible organic waste material to anaerobic digesters instead of sending it to landfills, better overall methane capture is possible as also reduction of gaseous and liquid emissions from landfills.

But anaerobic digestion of MSW is also besieged with serious problems:

1. The nature of organic waste in MSW may vary according to location and time of the year. In postharvest seasons, for example, levels of crop waste, leaf litter, etc. may be higher. This may lead to a variation in the $\mathrm{C} / \mathrm{N}$ ratio and affect the rate of gas production. 


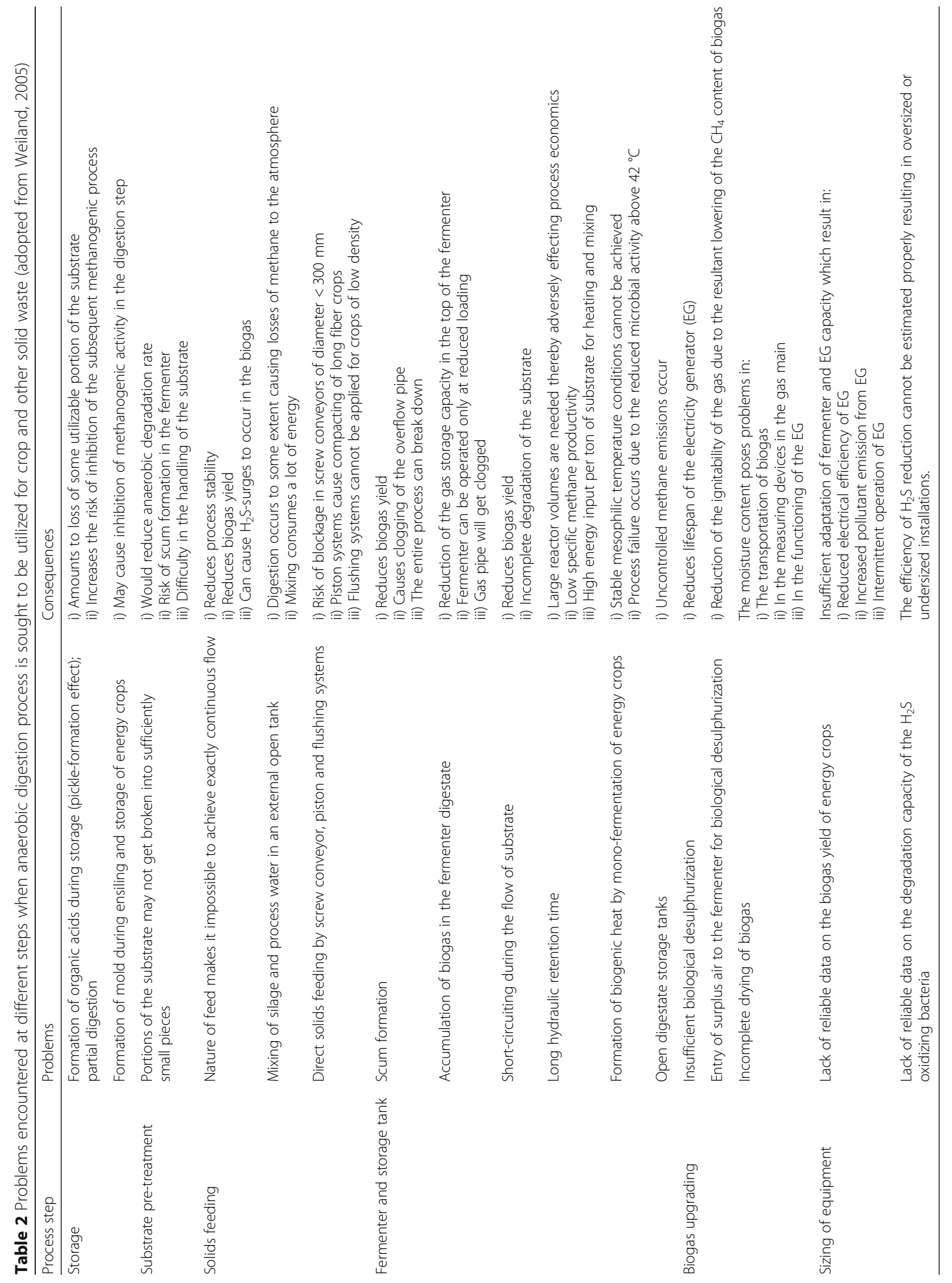


2. Inadequate mixing of refuse and sewage can affect the efficiency of the anaerobic digestion system.

3. Blockage of pipes can be caused if large pieces of waste enter the system. This problem is particularly common in continuous systems.

Table 2 lists the problems and the difficulties that they cause. Hence, widespread use of anaerobic digestion for large-scale treatment of MSW is a very remote possibility. Even if the process is made less costly than it is today, the possibility of it becoming a net energy producer is still very remote.

\section{Conclusions}

From the time some four decades ago when the MSW problem started becoming serious due to the increasing MSW generation across the world, efforts have been made by researchers, governments, industry and voluntary organizations to address this problem. There has been a particularly strong emphasis from the outset on recovery, reuse and recycling.

The expectation has been that these measures, together, may offset the monetary and environmental costs of MSW management. Particularly strong efforts have been made to develop technologies for the recovery of energy from MSW by direct use as fuel (incineration) or by converting MSW into gaseous or liquid fuels via landfilling, anaerobic digestion and other bioprocesses.

The state-of-the-art reveals that the generation of MSW has consistently outpaced the world's efforts to dispose it cleanly. It has become evident again and again that energy (and material) recovery from MSW is easier said than done. In most instances, what is technically feasible is economically unfeasible. And what is economically feasible-such as setting the waste on fire as is often done in developing countries-is exceedingly harmful to the environment and the human health. Measures such as sanitary landfilling and incineration create as many new problems as the old ones they solve. Moreover, despite the use of these less-than-adequate technologies, a major portion of MSW generated in the world lies untreated. As the MSW output is expected to double by 2025 , this situation is only set to become worse. Rising tides of a new solid waste stream that has begun to swell from the late 1990s onwards-E-wasteare threatening to compound the problem even further. Yet another new complication is emerging - of nanomaterials entering MSW. Hence, enormous stress should be put on the reduction of MSW generation by controlling wanton consumerism and wastage, rather than continuing with it in the false hope that technology will soon provide a magical solution and eliminate the problem.

\section{Abbreviations}

AD: Anaerobic digestion; CDM: Clean Development Mechanism; EG: Electricity generator; E-waste: Electronic waste; GHG: Global warming gas; LFG: Landfill gas; MSW: Municipal solid waste

\section{Acknowledgements}

SAA thanks the Council of Scientific and Industrial Research (CSIR), New Delhi, for the Emeritus Scientist position (21(1034)/16/EMR-II)

\section{Funding}

The work has not been based on any funding or other forms of support received from any source by the author.

\section{Author's contributions}

The author has read and approved the final manuscript.

Ethics approval and consent to participate

There were no living systems, including human subjects, used in this study. The information presented here does not contain any individual person's data.

\section{Competing interests}

The author declares that he has no competing interests.

\section{Publisher's Note}

Springer Nature remains neutral with regard to jurisdictional claims in published maps and institutional affiliations.

Received: 17 February 2018 Accepted: 2 October 2018

Published online: 19 November 2018

\section{References}

1. Abbasi T, Abbasi SA (2012) Is the use of renewable energy sources an answer to the problems of global warming and pollution? Crit Rev Environ Sci Technol 42:99-154

2. Abbasi T, Tauseef SM, Abbasi SA (2012) Biogas Energy. Springer, New Yark \& Londan xiv+169 pages; ISBN

3. Abbasi T, Tauseef SM, Abbasi SA (2012) Anaerobic digestion for global warming control and energy generation-an overview. Renew Sust Energ Rev 16:3228-3242

4. Abbasi AA, Jingsong G, Ping LZ, Ya PY, Al-Rekabi WS (2009) Review on landfill leachate treatments. J Appl Sci Res 5(5):534-545

5. Abbasi, S. A., and Ramasamy, E. V., (1999). Biotechnological methods of pollution control; Hydrabad: Orient longmans/UPIL, viii + 168 pp.

6. Abbasi T, Gajalakshmi S, Abbasi SA (2009) Towards modeling and design of vermicomposting systems: mechanisms of composting/vermicomposting and their implications. Indian J Biotechnol 8:177-182

7. Abbasi T, Abbasi SA (2010) Production of clean energy by anaerobic digestion of phytomass - new prospects, for a global warming amelioration technology. Renew Sust Energ Rev 14:1653-1659

8. Abbasi T, Abbasi SA (2010) Biomass energy and the environmental impacts associated with its production and utilization. Renew Sust Energ Rev 14: 919-937

9. Abbasi T, Abbasi SA (2011) Small hydro and the environmental implications of its extensive utilization. Renew Sust Energ Rev 15:2134-2143

10. Abbasi T, Abbasi SA (2011) Renewable' hydrogen: prospects and challenges. Renew Sust Energ Rev 15:3034-3040

11. Abbasi T, Abbasi SA (2011) Decorbonization of fossil fuels as a strategy to control global warming. Renew Sust Energ Rev 15:1928-1834

12. Abbasi, T., and Abbasi, S. A., (2018). Perspectives in pollution control and sustainable development. Discovery Publishing House, New Delhi; xi+569 pages

13. Abuabdou, S. M., Bashir, M. J., Aun, N. C., and Sethupathi, S., (2018). April. Applicability of anaerobic membrane bioreactors for landfill leachate treatment: Review and opportunity. In IOP Conference Series: Earth and Environmental Science, 140(1), 012033.

14. Abujayyab SK, Sanusi MS, Yahya AS, Alslaibi TM (2017). March) GIS modeling for landfill site selection via multi-criteria decision analysis: a systematic review. In: Proceedings of the International Conference on High Performance Compilation, Computing and Communications(pp. 33-38), ACM

15. Ahamed A, Yin K, Ng BJH, Ren F, Chang VC, Wang JY (2016) Life cycle assessment of the present and proposed food waste management 
technologies from environmental and economic impact perspectives. J Clean Prod 131:607-614

16. Ahmed SI, Johari A, Hashim H, Alkali H, Ramli M (2011) Renewable energy and carbon reduction potentials of municipal solid waste in Malaysia. In: 2011 IEEE 1st Conference on Clean Energy and Technology, CET 2011, art. no. 6041497, pp 280-286

17. Aja OC, Oseghale SD, Al-Kayiem HH (2014) Review and evaluation of municipal solid waste management practices in Malaysia. J Solid Waste Technol Manag 40(3):216-232. https://doi.org/10.5276/jswtm.2014.215

18. Akele ES, Tarekegn MM (2017) Assessment of dioxin and furan emission levels and management practices in Addis Ababa, Ethiopia. J Health and Pollution 7(15):85-94

19. Akinade OO, Oyedele LO, Ajayi SO, Bilal M, Alaka HA, Owolabi HA, Bello SA, Jaiyeoba BE, Kadiri KO (2017) Design for Deconstruction (DfD): Critical success factors for diverting end-of-life waste from landfills. Waste management, 60, pp.3-13.

20. Aleluia J, Ferrão P (2016) Characterization of urban waste management practices in developing Asian countries: a new analytical framework based on waste characteristics and urban dimension. Waste Manag 58:415-429

21. Alfaia RGSM, Costa AM, Campos JC (2017) Municipal solid waste in Brazil: a review. Waste Manag Res 35(12):1195-1209. https://doi.org/10.1177/ $0734242 \times 17735375$

22. Annepu RK (2012) Sustainable solid waste management in India. Columbia University, New York, 2(01)

23. Arena U (2012) Process and technological aspects of municipal solid waste gasification A review. Waste Manag 32(4):625-639

24. Asakura H, Matsuto T, Inoue Y (2010) Adopted technologies and basis for selection at municipal solid waste landfill facilities constructed in recent years in Japan. Waste Manag Res 28(8):685-694

25. Baere LD, Mattheeuws B (2010) Anaerobic digestion of MSW in Europe. BioCycle, 51(2), pp.24-26.

26. Banupriya, D., (2017). Towards development of mechanizable high-rate vermicomposting systems for converting biodegradable solid waste into organic fertilizers, PhD Thesis, Pondicherry University, Puducherry, pp 240.

27. Bedi A (2018) The Greater Kailash of garbage. Oulook 58(16):34-39

28. Ben Y, Li T, Wan Y, Dong Z, Hu J (2017) Exposure assessment of PCDD/Fs for the population living in the vicinity of municipal waste incinerator: additional exposure via local vegetable consumption. Environ Pollut 224: 532-540

29. Beyene HD, Werkneh AA, Ambaye TG (2018) Current updates on waste to energy (WtE) technologies: a review. Renewable Energy Focus 24:1-11

30. Bilgili MS, Demir A, Ozkaya B (2004) Effects of recirculation on leachate characteristics at landfills. Fresenius Environ Bull 13(10):1000-1005

31. Blight $G$ (2008) Slope failures in municipal solid waste dumps and landfills: a review. Waste Manag Res 26(5):448-463

32. Bolan NS, Thangarajan R, Seshadri B, Jena U, Das KC, Wang H, Naidu R (2013) Landfills as a biorefinery to produce biomass and capture biogas. Bioresour Technol 135:578-587

33. Bharathiraja B, Sudharsanaa T, Bharghavi A, Jayamuthunagai J, Praveenkumar R (2016) Biohydrogen and biogas - an overview on feedstocks and enhancement process. Fuel 185:810-828. https://doi.org/10. 1016/j.fuel.2016.08.030

34. Bong CPC, Lim LY et al (2018) Review on the characteristic and feasibility of leachate for biogas production by anaerobic digestion. Chem Eng Trans 63: 73-78

35. Brandes W, Themelis NJ (2011) Materials and energy recovery from municipal solid waste: why they are both needed. 19th Annual North American Waste-to-Energy Conference, NAWTEC19, pp 127-142

36. Burlakovs J, Kriipsalu M, Klavins M, Bhatnagar A, Vincevica-Gaile Z, Stenis J, Jani Y, Mykhaylenko V, Denafas G, Turkadze T, Hogland M (2017) Paradigms on landfill mining: from dump site scavenging to ecosystem services revitalization. Resour Conserv Recycl 123:73-84

37. Canopoli L, Fidalgo B, Coulon F, Wagland ST (2018) Physico-chemical properties of excavated plastic from landfill mining and current recycling routes. Waste Manag

38. Chai X, Tonjes DJ, Mahajan D (2016) Methane emissions as energy reservoir: context, scope, causes and mitigation strategies. Prog Energy Combust Sci 56:33-70. https://doi.org/10.1016/j.pecs.2016.05.001

39. Chakraborty P, Selvaraj S, Nakamura M, Prithiviraj B, Cincinelli A, Bang J J (2018) PCBs and PCDD/Fs in soil from informal e-waste recycling sites and open dumpsites in India: levels, congener profiles and health risk assessment. Sci Total Environ 621:930-938

40. Chan MT, Selvam A, Wong JW (2016) Reducing nitrogen loss and salinity during 'struvite' food waste composting by zeolite amendment. Bioresource technology, 200, pp.838-844.

41. Chen D, Christensen TH (2010) Life-cycle assessment (EASEWASTE) of two municipal solid waste incineration technologies in China. Waste Manag Res 28(6):508-519

42. Chen WY, Wu JH, Lin SC, Chang JE (2016) Bioremediation of polychlorinated-p-dioxins/dibenzofurans contaminated soil using simulated compost-amended landfill reactors under hypoxic conditions. J Hazard Mater 312:159-168

43. Cheng H, Hu Y (2010) Curbing dioxide emissions from municipal solid waste incineration in China: re-thinking about management policies and practices. Environ Pollut 158(9):2809-2814

44. Cheng H, Hu Y (2010) Municipal solid waste (MSW) as a renewable source of energy: Current and future practices in China. Bioresource technology, 101(11), 3816-3824.

45. Chi X, Streicher-Porte M, Wang MYL, Reuter MA (2011) Informal electronic waste recycling: a sector review with special focus on China. Waste Manag 31(4):731-742

46. Chidambarampadmavathy K, Karthikeyan OP, Heimann K (2017) Sustainable bio-plastic production through landfill methane recycling. Renew. Sustain. Energy Rev. 71 555-562. https://doi.org/10.1016/j.rser.2016.12.08.

47. Clarke WP (2018) The uptake of anaerobic digestion for the organic fraction of municipal solid waste - push versus pull factors. Bioresour Technol 249: 1040-1043. https://doi.org/10.1016/j.biortech.2017.10.086

48. Cuartas M, López A, Pérez F, Lobo A (2018) Analysis of landfill design variables based on scientific computing. Waste Manag 71:287-300

49. Davis G, Phillips PS, Coskeran T (2009) Driving commercial and industrial waste reduction in Queensland, Australia: the potential application of a UK waste minimisation club model. J Solid Waste Technol Manag 35(1):50-62

50. De Baere L, Mattheeuws B (2010) Anaerobic digestion of MSW in EUROPE. BioCycle 51(2):24-26

51. Dhar H, Kumar S, Kumar R (2017) A review on organic waste to energy systems in India. Bioresour Technol 245:1229-1237. https://doi.org/10.1016/j. biortech.2017.08.159

52. Dong $L$, Zhenhong $Y$, Yongming $S$ (2010) Semi-dry mesophilic anaerobic digestion of water sorted organic fraction of municipal solid waste (WSOFMSW). Bioresour Technol 101(8):2722-2728

53. Doron A, Jeffry R (2018) Incentivise with tools. Oulook 58(16):42-44

54. Douglas P, Freni-Sterrantino A, Leal Sanchez M, Ashworth DC, Ghosh RE, Fecht D, Font A, Blangiardo M, Gulliver J, Toledano MB, Elliott P (2017) Estimating particulate exposure from modern municipal waste incinerators in Great Britain. Environ Sci Technol 51(13):7511-7519

55. Du Y, Fang $Y$, Shen D, Long $Y$ (2015) Review on pollution control technologies of hydrogen sulfide odor in landfill. Nongye Gongcheng Xuebao/Transactions of the Chinese Society of Agricultural Engineering 31: 269-275. https://doi.org/10.3969/j.issn.1002-6819.2015.21.032

56. Edwards J, Othman M, Burn S (2015) A review of policy drivers and barriers for the use of anaerobic digestion in Europe, the United States and Australia. Renew Sust Energ Rev 52:815-828

57. EUROSTAT (2015). Sustainable development indicators, http://ec.europa.eu/ eurostat/web/ sdi/ indicators (01.2015)

58. EUROSTAT. (2010). WEEE collection rate <https://ec.europa.eu/eurostat/>. Accessed Oct 2012.

59. Ezeah C, Roberts CL (2012) Analysis of barriers and success factors affecting the adoption of sustainable management of municipal solid waste in Nigeria. J Environ Manag 103:9-14

60. Fajković H, Ivanić M, Pitarević L, Nemet I, Rončević S, Prohić E (2018) Unsanitary landfill fires as a source of a PCDD/Fs contamination. Croat Chem Acta 91(1):71-79

61. Farzadkia M, Jorfi S, Akbari H, Ghasemi M (2012) Evaluation of dry solid waste recycling from municipal solid waste: case of Mashhad city, Iran. Waste Manag Res 30(1):106-112

62. Fazeli A, Bakhtvar F et al (2016) Malaysia's stand on municipal solid waste conversion to energy: a review. Renew Sust Energ Rev 58:1007-1016

63. Fdez-Güelfo LA, Álvarez-Gallego C, Sales D, Romero García LI (2012) Drythermophilic anaerobic digestion of organic fraction of municipal solid waste: methane production modeling. Waste Manag 32(3):382-388 
64. Fernández Rodríguez J, Pérez M, Romero LI (2012) Mesophilic anaerobic digestion of the organic fraction of municipal solid waste: optimisation of the semicontinuous process. Chem Eng J 193-194:10-15

65. Ferrer I, Ponsá S, Vázquez F, Font X (2008) Increasing biogas production by thermal $(70 \mathrm{C})$ sludge pre-treatment prior to thermophilic anaerobic digestion. Biochem Eng J 42(2):186-192

66. Francois V, Feuillade G, Matejka G, Lagier T, Skhiri N (2007) Leachate recirculation effects on waste degradation: study on columns. Waste Manag 27(9):1259-1272

67. Ganesh, G., Karthikeyan, O. P., and Joseph, K. (2010). Enhancing the hydrolysis step in anaerobic digestion of municipal solid waste using rumen fluid, International Journal of Environmental Technology and Management,13(3-4), 311-321

68. Gomez E, Rani DA, Cheeseman CR, Deegan D, Wise M, Boccaccini AR (2009) Thermal plasma technology for the treatment of wastes, a critical review. J Hazard Mater 161:614-626

69. Gómez-Lavín S, San Román MF, Ortiz I, Fernández J, de Miquel P, Urtiaga A (2018) Dioxins and furans legacy of lindane manufacture in Sabiñánigo (Spain), The Bailín landfill site case study. Sci Total Environ 624:955-962

70. Goncalves-Araujo R, Rabe B, Peeken I, Bracher A (2018) High colored dissolved organic matter (CDOM) absorption in surface waters of the central-eastern Arctic Ocean: Implications for biogeochemistry and ocean color algorithms. PloS one, 13(1), 0190838.

71. Grando LR, de Souza Antune AM, da Fonseca FV, Sánchez A, Barrena R, Font $X$ (2017) Technology overview of biogas production in anaerobic digestion plants: a European evaluation of research and development. Renew Sust Energ Rev 80:44-53. https://doi.org/10.1016/j.rser.2017.05.079

72. Grant R, Oteng-Ababio M (2012) Mapping the invisible and real African economy: urban e-waste circuitry. Urban Geogr 33(1):1-21

73. Grech S (2015) Disability and poverty in the global South: Renegotiating development in Guatemala. Springer.

74. Gugele B, Ritter M, Mareckova K (2002) Greenhouse gas emission trends in Europe, 1990-2000, topic report 7/2002. Copenhagen, European Environment Agency

75. Guo Y, Huo X, Wu K, Liu J, Zhang Y, Xu X (2012) Carcinogenic polycyclic aromatic hydrocarbons in umbilical cord blood of human neonates from Guiyu, China. Sci Total Environ 427-428:35-40

76. Hagelüken C, Meskers CEM (2008) Mining our computers - opportunities and challenges to recover scarce and valuable metals from end-of-life electronic devices. In: Reichl H et al (eds) Electronics goes green 2008. Fraunhofer IRB Verlag, Stuttgart, pp 623-628

77. Hamid H, Li LY, Grace JR (2018) Review of the fate and transformation of per- and polyfluoroalkyl substances (PFASs) in landfills. Environ Pollut 235: 74-84. https://doi.org/10.1016/j.envpol.2017.12.030

78. Han Z, Ma H, Shi G, He L, Wei L, Shi Q (2016) A review of groundwater contamination near municipal solid waste landfill sites in China. Sci Total Environ 569-570:1255-1264. https://doi.org/10.1016/ j.scitotenv.2016.06.201

79. Hashisho J, El-Fadel M (2014) Determinants of optimal aerobic bioreactor landfilling for the treatment of the organic fraction of municipal waste. Crit Rev Environ Sci Technol 44(16):1865-1891. https://doi.org/10.1080/ 10643389.2013.803798

80. Hettiaratchi P, Jayasinghe PH, Tay J, Yadav S (2015) Recent advances of biomass waste to gas using landfill bioreactor technology-a review. Curr Org Chem 19(5):413-422

81. Heyer KU, Hupe K, Stegmann R (2013) Methane emissions from MBT landfills. Waste Manag 33(9):1853-1860

82. Hodson EL, Martin D, Prinn RG (2010) The municipal solid waste landfill as a source of ozone-depleting substances in the United States and United Kingdom. Atmos Chem Phys 10(4):1899-1910

83. Holmes T, Baker B, Shoemaker $L$ (2016) Materials for service in municipal waste- \& biomass-fired power generation... a review of recent experience. In: NACE International Corrosion Conference Proceedings (p. 1). NACE International

84. Holmes, T., Baker, B., and Shoemaker, L., (2016). Materials for Service in Municipal Waste-\& Biomass-Fired Power Generation... a Review of Recent Experience. In NACE International Corrosion Conference Proceedings (p. 1) NACE International.

85. Hossain, M. S., Haque, M. A., and Hoyos, L. R., (2010). Dynamic properties of municipal solid waste in bioreactor landfills with degradation. Geotechnical and Geological Engineering, 28(4), 391-403.
86. Huang TY, Chuieh PT (2015) Life cycle assessment of reusing fly ash from municipal solid waste incineration. Procedia Engineering 118:984-991

87. Hunte, C. A, (2010). Performance of a full-scale bioreactor landfill. PhD Thesis Department of Civil Engineering University of Calgary

88. Kerr, T., and Dargaville, R., (2008). Turning a liability into an asset: Landfil methane utilisation potential in India. International Energy Agency, 5-9.

89. Indelicato S, Orecchio S, Avellone G, Bellomo S, Ceraulo L, Di Leonardo R, Di Stefano V, Favara R, Candela EG, La Pica L, Morici S (2017) Effect of solid waste landfill organic pollutants on groundwater in three areas of Sicily (Italy) characterized by different vulnerability. Environ Sci Pollut Res 24(20): 16869-16882

90. Jacob, B. A., and Ayers, M. R., (2017). Everything you ever wanted to know about solar energy landfill solar: trash to treasure. WEEC 2017 - orld Energy Engineering Congress, Proceedings

91. Jayasinghe PA, Hettiaratchi JPA, Mehrotra AK (2014) Reaction mechanism and rate constants of waste degradation in landfill bioreactor systems with enzymatic-enhancement. Bioresour Technol 162:279-282

92. Jayasinghe PA, Hettiaratchi JPA, Mehrotra AK, Kumar SK (2011) Enzymatic enhancement of leachate to increase gas production in landfill bioreactors. Bioresour Technol 102(7):4633-4637

93. Jayasinghe PA, Hettiaratchi JPA, Mehrotra AK, Steele MA (2013) Enhancing gas production in landfill bioreactors: a flow-through column study on leachate augmentation with enzyme. J Hazard Tox Radioact Waste 17(4): 253-258

94. Jia MS, Wang XJ, Chen SH (2014) Nitrous oxide emissions from municipal solid waste landfills and its measuring methodology: a review. Chin J Appl Ecol 25(6):1815-1824

95. Johari A, Ahmed SI, Hashim H, Alkali H, Ramli M (2012) Economic and environmental benefits of landfill gas from municipal solid waste in Malaysia. Renew Sust Energ Rev 16(5):2907-2912

96. Karak T, Bhagat RM, Bhattacharyya P (2012) Municipal solid waste generation, composition, and management: the world scenario. Crit Rev Environ Sci Technol 42(15):1509-1630

97. Kexue Ban/Acta Scientiarum Naturalium Universitatis Pekinensis 46(4), 674-680

98. Khajuria A, Matsui T, Machimura T, Morioka T (2012) Decoupling and Environmental Kuznets Curve for municipal solid waste generation: evidence from India. Agris On-line Papers in Economics and Informatics 2(3):1670-1674

99. Kocasoy G, Curi K (1995) The Ümraniye-Hekimbaşi open dump accident. Waste Manag Res 13(4):305-314

100. Ko JH, Xu Q, Jang YC (2015) Emissions and control of hydrogen sulfide at landfills: a review. Crit Rev Environ Sci Technol 45(19):2043-2083. https://doi. org/10.1080/10643389.2015.1010427

101. Kollikkathar N, Feng H, Stern E (2009) A purview of waste management volution: special emphasis on USA. Waste Manag 29:974-985

102. Komilis D, Evangelou A, Giannakis G, Lymperis C (2012) Revisiting the elemental composition and the calorific value of the organic fraction of municipal solid wastes. Waste management, 32(3), 372-381.

103. Krishna G (2017) Why urban waste continues to follow the path of least resistance. Econ Polit Wkly 52(17):95-101

104. Kumar S, Chiemchaisri C, Mudhoo A (2011) Bioreactor landfill technology in municipal solid waste treatment: an overview. Crit Rev Biotechnol 31(1):77-97

105. Kumar, A., Datta, M., Nema, A. K., Singh, R. K., \& Gurjar, B. R., (2018). Improved rating system for hazard assessment related to subsurface migration of landfill gas from municipal solid waste landfills and dumps. J Hazard Toxic, and Radioactive Waste, 22(3). doi: https://doi. org/10.1061/(asce)hz.2153-5515.0000393

106. Kuo JH, Lin CL, Chen JC, Tseng HH, Wey MY (2011) Emission of carbon dioxide in municipal solid waste incineration in Taiwan: a comparison with thermal power plants. Int J Greenhouse Gas Control 5:889-898

107. Laner D, Crest M, Scharff H, Morris JWF, Barlaz MA (2012) A review of approaches for the long-term management of municipal solid waste landfills. Waste Manag 32(3):498-512

108. Li G, Wu Q, Wang S, Duan Z, Su H, Zhang L, Li Z, Tang Y, Zhao M, Chen L, Liu K (2018) Improving flue gas mercury removal in waste incinerators by optimization of carbon injection rate. Environ Sci Technol 52(4):1940-1945

109. Li J, Wang C, Du L, Lv Z, Li X, Hu X, Niu Z, Zhang Y (2017) Did municipal solid waste landfill have obvious influence on polychlorinated dibenzo-pdioxins and polychlorinated dibenzofurans (PCDD/Fs) in ambient air: a case study in East China. Waste Manag 62:169-176 
110. Li J, Zhang Y, Sun T, Hao H, Wu H, Wang L, Chen Y, Xing L, Niu Z (2018) The health risk levels of different age groups of residents living in the vicinity of municipal solid waste incinerator posed by PCDD/Fs in atmosphere and soil. Sci Total Environ 631:81-91

111. Lin X, Chen Z, Lu S, Zhang S, Zhang M, Li X, Yan J (2018) Emission characteristics of polychlorinated dibenzo-p-dioxins and dibenzofurans from the co-combustion of municipal solid waste in a lab-scale drop-tube furnace. Energy Fuel 32(4):5396-5404

112. Liu S, Jiang CS, Hao QJ, Li QL, Shi Y (2012) The particle size distribution, gross contents of heavy metals and its leaching behavior of fly ash from municipal solid wastes incineration of Chongqing. Adv Mater Res 414:166-171

113. Lohri CR, Faraji A, Ephata E, Rajabu HM, Zurbrügg C (2015) Urban biowaste for solid fuel production: waste suitability assessment and experimental carbonization in Dar es Salaam, Tanzania. Waste Manag Res 33(2):175-182

114. Lu JW, Zhang S, Hai J, Lei M (2017) Status and perspectives of municipal solid waste incineration in China: A comparison with developed regions. Waste Management, 69, 170-186. https://doi.org/10. 1016/j.wasman.2017.04.014

115. Mali Sandip T, Khare Kanchan C, Biradar Ashok H (2012) Enhancement of methane production and bio-stabilisation of municipal solid waste in anaerobic bioreactor landill. Bioresour Technol 110:10-17

116. Malinauskaite J, Jouhara H, Czajczyńska D, Stanchev P, Katsou E, Rostkowski P, Spencer N (2017) Municipal solid waste management and waste-to-energy in the context of a circular economy and energy recycling in Europe. Energy 141:2013-2044. https://doi.org/10.1016/j. energy.2017.11.128

117. Mandal P, Dubey BK, Gupta AK (2017) Review on landfill leachate treatment by electrochemical oxidation: drawbacks, challenges and future scope. Waste Manag

118. Margallo M, Taddei MBM, Hernández-Pellón A, Aldaco R, Irabien A (2015) Environmental sustainability assessment of the management of municipal solid waste incineration residues: a review of the current situation. Clean Techn Environ Policy 17(5):1333-1353

119. Mascarenhas AM, Sutherland JJ (2015) What is all this talk about emissions? J Pet Technol 67(11):23-25

120. Mazumdar NB (2013) MSW to energy in India: the scenario and expectations. Ministry of New and Renewable Energy, India

121. Merry SM, Kavazanjian E, Fritz WU (2005) Reconnaisance of the July 10 2000, Payatas landfill failure. ASCE J Performance of Constructed Facilities 19:100-107

122. Mendez AP, Ridao AR, Toro MZ (2008) Environmental diagnosis and planning actions for municipal waste landfills in Estado Lara (Venezuela). Renew Sust Energ Rev 12(3):752-771

123. Meraz RL, Vidales AM, Domínguez A (2004) A fractal-like kinetics equation to calculate landfill methane production. Fuel 83:73-80

124. Mian MM, Zeng X, Nasry ANB, Al-Hamadani SMZF (2017) Municipal solid waste management in China: a comparative analysis. J Mater Cycles Waste Manag 19(3):1127-1135. https://doi.org/10.1007/s10163-016-0509-9

125. Miroslav N, Therrien R, Lefebvre R, Gaclinas P (2001) Gas production and migration in landfill and geological materials. J Contamination Hidrol 52: 187-211

126. Minh, N. H., Anh, D.H., Tri, T. M., Anh, H. Q., Mai, P. T. N., Nam, V. D., Viet, P. H. and Minh, T. B., (2016). c. In Persistent organic chemicals in the environment: status and trends in the Pacific Basin Countries I contamination status (pp. 55-83). American Chemical Society

127. MNRE-Ministry of New and Renewable Energy. Govt. of India. Annual Report 2010-11. 2011. http://www.mnre.gov.in/. Accessed 19 May 2011

128. Moyna (2012) What a waste. Down To Earth 21(10):18-19

129. Moyna (2012) Patronising dirty technology. Down To Earth 20(23):9-10

130. Nadal M, Rovira J, Díaz-Ferrero J, Schuhmacher M, Domingo JL (2016) Human exposure to environmental pollutants after a tire landfill fire in Spain: health risks. Environ Int 97:37-44

131. Nadal M, Rovira J, Sánchez-Soberón F, Schuhmacher M, Domingo JL (2016) Concentrations of metals and PCDD/Fs and human health risks in the vicinity of a hazardous waste landfill: a follow-up study human and ecological risk assessment. An Int J 22(2):519-531

132. Nadaletti WC, Cremonez PA et al (2015) Potential use of landfill biogas in urban bus fleet in the Brazilian states: a review. Renewable and Sustainable Energy Reviews 41:277-283
133. Naveen BP, Mahapatra DM, Sitharam TG, Sivapullaiah PV, Ramachandra TV (2017) Physico-chemical and biological characterization of urban municipal landfill leachate. Environ Pollut 220:1-12. https://doi.org/10.1016/j.envpol. 2016.09.002

134. Nayar L (2018) Keep it simple, stupid. Outlook 28:40-41

135. Nelles M, Grünes J, Morscheck G (2016) Waste management in Germany-development to a sustainable circular economy? Procedia Environ Sci 35:6-14

136. Ngusale GK, Oloko M, Agong S, Nyakinya B (2017). Energy recovery from municipal solid waste. Energy Sources, Part A: recovery, utilization and environmental effects, 39(16), 1807-1814. doi: https://doi.org/10.1080/ 15567036.2017 .1376007

137. OECD. Publishing (2017). OECD Digital Economy Outlook 2017. OECD Publishing.

138. Ogwueleka TC, Ogwueleka N (2010) Modelling energy content of municipal solid waste using artificial neural network.

139. Ouda OKM, Raza SA (2014) Waste-to-energy: solution for municipal solid waste challenges-global perspective. ISTMET 2014 - 1st international symposium on technology management and emerging technologies, Proceedings

140. Pacey J, Augenstein D, Morck R, Reinhart D Yazdani R (1999). The bioreactor landfill-an innovation in solid waste management. MSW management, 53-60.

141. Park S (2018) Factors influencing the recycling rate under the volume-based waste fee system in South Korea. Waste Manag 74:43-51

142. Part F, Berge N, Baran P, Stringfellow A, Sun W, Bartelt-Hunt S, Mitrano D, Li L, Hennebert P, Quicker P, Bolyard SC (2018) A review of the fate of engineered nanomaterials in municipal solid waste streams. Waste Manag 75:427-449

143. Pohland FG, Al-Yousfi AB, Reinhart DR (2003) Anaerobic digestion of organic solid waste in bioreactor landfills. In: Mata-Alvarez J (ed) Biomethanization of the organic fraction of municipal solid waste. IWA Publishing, pp 303-315

144. Pollock, C., (1987). Mining urban wastes: the potential for recycling. Worldwatch paper (USA). no. 76.

145. Premalatha M, Tauseef SM, Abbasi T, Abbasi SA (2012) The real origin of the e-waste problem and its truly 'sustainable' solution. Ecolo Environ Conserv 18:987-991

146. Premalatha M, Tabassum-Abbasi, Abbasi T, Abbasi SA (2014) A critical view on the eco-friendliness of small and large hydroelectric installations. Sci Total Environ 481:638--643

147. Premalatha M, Tabassum A, Abbasi T, Abbasi SA (2014) The generation, impact, and management of E-waste: state of the art. Crit Rev Environ Sci Technol 44(14):1577-1678. https://doi.org/10.1080/10643389.2013.782171

148. Purger D, Lengyel A, Kevey B, Lendvai G, Horváth A, Tomić Z Csiky J (2014) Numerical classification of oak forests on loess in Hungary, Croatia and Serbia. Preslia, 87, 47-66

149. Ramasamy EV, Abbasi SA (2000) High-solids anaerobic digestion for the recovery of energy from municipal solid waste (MSW). Environ Technol 21(3):345-349

150. Ramasamy EV, Abbasi SA (1999) Utilization of biowaste solids by extracting volatile fatty acids with subsequent conversion to methane and manure. J Solid Waste Technol Manag 26(3):133-139

151. Rapport JL, Zhang R, Williams RB, Jenkins BM (2012) Anaerobic digestion technologies for the treatment of municipal solid waste. Int J Environ Waste Manag 9(1-2):100-122

152. Reinhart, D. R., McCreanor, P. T., . Townsend, T. (2002) The bioreactor landfill: its status and future. Waste Manage Res, 20(2), 172-186

153. Ritzkowski M, Stegmann R (2007) Controlling greenhouse gas emissions through landfill in situ aeration. Int J Greenhouse Gas Control 1(3):281-288

154. Rostron J (2008) The law and regulation of waste in the United Kingdom: a review. Environ Qual Manag 18(1):47-65

155. Roumak VS, Umnova NV, Levenkova ES, Turbabina KA, Pivovarov EA Shelepchikov AA, Pavlov SD (2017) Dioxins in the environment and the body of animals near landfill: to the methodology of public health risk evaluation. Ekologiya Cheloveka/Human Ecology 10:9-15

156. Rovira J, Nadal M, Schuhmacher M, Domingo JL (2018) Concentrations of trace elements and PCDD/Fs around a municipal solid waste incinerator in Girona (Catalonia, Spain) Human health risks for the population living in the neighborhood. Sci Total Environ 630:34-45

157. Sapkal VR, Chandel MK et al (2016) Treatment of municipal solid waste leachate: a review. J Environ Sci Engineering 58(2):167-174 
158. Sarkar C, Abbasi SA (2006) QUALIDEX: a virtual instrument for continuous monitoring of water quality indices. Environ Monit Assess 119:201-231

159. Schindell DT, Faluvegi G, Koch DM, Schmidt GA, Unger N, Bauer SE (2009) Improved attribution of climate forcing to emissions. Science, 326(5953): 716-718. Shaltout, K.H., Al-Sodany, Y.M. and Eid, E.M.

160. Selvi PK, Akolkar AB, Saranya P (2012) Occupational health hazards of the working group associated with municipal solid waste management at Kolkata in eastern India. Int J Environ Health 6(2):141-154

161. Shehzad A, Bashir MJK, Sethupathi S, Lim JW, Younas M (2016) Bioelectrochemical system for landfill leachate treatment - challenges, opportunities, and recommendations. Geosystem Engineering 19(6):337345. https://doi.org/10.1080/12269328.2016.1188029

162. Shen H, Guan R, Ding G, Chen Q, Lou X, Chen Z, Zhang L, Xing M, Han J, Wu Y (2017) Polychlorinated dibenzo-p-dioxins/furans (PCDD/Fs) and polychlorinated biphenyls (PCBs) in Zhejiang foods (2006-2015): market basket and polluted areas. Sci Total Environ 574:120-127

163. Siddiqui FZ, Zaidi S, Pandey S, Khan ME (2013) Review of past research and proposed action plan for landfill gas-to-energy applications in India. Waste Manag Res 31(1):-3

164. Singh RP, Tyagi W, Allen T, Ibrahim MH, Kothari R (2011) An overview for exploring the possibilities of energy generation from municipal solid waste (MSW) in Indian scenario. Renew Sust Energ Rev 15(9):4797-4808

165. Soler A, Conesa JA, Iñiguez ME, Ortuño N (2018) Pollutant formation in the pyrolysis and combustion of materials combining biomass and e-waste. Sci Total Environ 622:1258-1264

166. Song Q, Wang Z, Li J, Duan H, Yu D, Liu G (2017) Comparative life cycle GHG emissions from local electricity generation using heavy oil, natural gas, and MSW incineration in Macau. Renew Sust Energ Rev

167. Srogi K (2008) Levels and congener distributions of PCDDs PCDFs and dioxin-like PCBs in environmental and human samples: a review. Environ Chem Letters 6:1-28

168. Su G, Letcher RJ, Farmahin R, Crump D (2018) Photolysis of highly brominated flame retardants leads to time-dependent dioxin-responsive mRNA expression in chicken embryonic hepatocytes. Chemosphere 194: 352-359

169. Surroop D, Mohee R (2011) Comparative assessment of anaerobic digestion of municipal solid waste at mesophilic and thermophilic temperatures. Int J Environ Technol Manag 14(1-4):238-251

170. Swati M, Karthikeyan OP, Joseph K, Visvanathan C, Nagendran R (2011) Pilotscale simulation of landfill bioreactor and controlled dumping of fresh and partially stabilized municipal solid waste in a tropical developing country. J Hazard Toxic, and Radioactive Waste 15(4):321-330

171. Tao T, Sondalle SB, Shi H, Zhu S, Perez-Atayde AR, Peng J, Baserga SJ, Look AT (2017) The pre-rRNA processing factor DEF is rate limiting for the pathogenesis of MYCN-driven neuroblastoma. Oncogene, 36(27), p.3852.

172. Tauseef SM, Abbasi T, Abbasi SA (2013) Energy recovery from wastewaters with high-rate anaerobic digesters. Renew Sust Energ Rev 19:704-741

173. Tauseef SM, Premalatha M, Abbasi T, Abbasi SA (2013) Methane capture from livestock manure. J Environ Manag 117:187-207

174. Tian M, Chen SJ, Wang J, Luo Y, Luo XJ, Mai BX (2012) Plant uptake of atmospheric brominated flame retardants at an e-waste site in southern China. Environ Sci Technol 46(5):2708-2714

175. Thanh NP, Matsui Y (2013) Assessment of potential impacts of municipal solid waste treatment alternatives by using life cycle approach: a case study in Vietnam. Environ Monit Assess 185(10):7993-8004. https://doi.org/10. 1007/s10661-013-3149-8

176. Tonjes DJ, Greene KL (2012) A review of national municipal solid waste generation assessments in the USA. Waste Manag Res 30(8):758-771

177. Tran LTH, Rollon AP, Nakasaki K (2012) Anaerobic digestion of organic fraction of municipal solid waste (OFMSW) in two-phase system. Int J Environ Waste Manag 9(1-2):5-17

178. Tsydenova O, Bengtsson M (2011) Chemical hazards associated with treatment of waste electrical and electronic equipment. Waste Manag 31(1):45-58

179. UNEP (2009) Recycling — from E-waste to Resources. United Nations Environment Programme pp xxiv+90

180. Habitat, U. N., (2010). The state of African cities 2010: Governance, inequality and urban land markets. United Nations Environment Programme, United Nations.
181. United Nation Development Programme (UNDP)/World Health Organization (WHO). The energy access situation in developing countries: a review focusing on the least developed countries and Sub-Saharan Africa UNDP, New York, United States; 2009.

182. (UNSTATS) (2018): United Nations Statistics Division IAEG-SDGs. Tier classification for global SDG indicators. URL: https://unstats.un.org/sdgs/ iaeg-sdgs/tier-classification/ (09.03.2018)

183. USEPA (1996) Opportunities for landfill gas energy recovery in WisconsinDraft profiles of candidate landfills and current projects, report no. 430B96031, p 132

184. USEPA (2018). Landfill methane outreach program. www.epa.gov/lmop

185. USEPA (2011) Global anthropogenic non- $\mathrm{CO}_{2}$ greenhouse gas emission: 1990-2030, EPA 430-D-11-003. United States Environmental Protection Agency available online at URL: www.epa.gov, Accessed: Oct 2012

186. Vaish B, Sharma B, Srivastava V, Singh P, Ibrahim MH, Singh RP (2017) Energy recovery potential and environmental impact of gasification for municipal solid waste. Biofuels:1-14. https://doi.org/10.1080/17597269.2017.1368061

187. Valerio $F$ (2008) Review on environmental impact of solid wastes produced by municipal urban waste incinerators. Epidemiol Prev 32:244-253

188. Vergara SE, Tchobanologus G (2012) Municipal solid waste and the environment: a global perspective. Annu Rev Environ Resour 37:277-309

189. Vinceti M, Malagoli C, Werler MM, Filippini T, De Girolamo G, Ghermandi G, Fabbi S, Astolfi G, Teggi S (2018) Adverse pregnancy outcomes in women with changing patterns of exposure to the emissions of a municipal waste incinerator. Environ Res 164:444-451

190. Vourdoubas J, Skoulou VK (2016) Case study of viability of bioenergy production from landfill gas (LFG). J Agric Sci 8(10):165

191. Wei GX, Liu HQ, Zhang R, Zhu YW, Xu X (2016) Mass concentrations of polychlorinated dibenzo-p-dioxins and dibenzofurans (PCDD/Fs) and heavy metals in different size fractions of hospital solid waste incinerator fly ash particles. Aerosol Air Qual Res 16:1569-1578

192. Wang H, Brown SL, Magesan GN, Slade AH, Quintern M, Clinton PW, Payn TW (2008) Technological options for the management of biosolids. Environ Sci Pollut Res 15:308-317

193. Wang JJ, Zhao HW, Zhong XP, Liu YS, Zeng H (2011) Concentration levels and spatial distribution of heavy metals in soil surrounding a municipal solid waste incineration plant (Shenzhen). Huanjing Kexue/Environmental Science 32(1):298-304

194. Wang R, Xu Z (2014) Recycling of non-metallic fractions from waste electrical and electronic equipment (WEEE): a review. Waste Manag 34(8): 1455-1469. https://doi.org/10.1016/j.wasman.2014.03.004

195. Wang Y, Yan Y, Chen G, Zuo J, Du H (2015) Effective approaches to reduce greenhouse gas emissions from waste to energy process: a China study. Resour Conserv Recycl 104:103-108

196. Weng YC, Fujiwara T, Houng HJ, Sun CH, Li WY, Kuo YW (2015) Management of landfill reclamation with regard to biodiversity preservation, global warming mitigation and landfill mining: experiences from the Asia-Pacific region. J Clean Prod 104:364-373. https://doi.org/10.1016/j. jclepro.2015.05.014

197. WI (Solid Waste Management in the World's Institute), 2012. Global municipal solid waste continues to grow. http://www.worldwatch.org/ global-municipal-solid-waste-continues-grow-0.

198. Wu D, Wang T, Huang X, Dolfing J, Xie B (2015) Perspective of harnessing energy from landfill leachate via microbial fuel cells: novel biofuels and electrogenic physiologies. Appl Microbiol Biotechnol 99(19):7827-7836. https://doi.org/10.1007/s00253-015-6857-x

199. Xevgenos D, Papadaskalopoulou C, Panaretou V, Moustakas K, Malamis D (2015) Success stories for recycling of MSW at municipal level: a review. Waste and Biomass Valorization 6(5):657-684

200. Yi S, Jang YC (2018) Life cycle assessment of solid refuse fuel production from MSW in Korea. J Mater Cycles and Waste Manag 20(1):19-42

201. Zamorano M, Ignacio Pérez Pérez J, Aguilar Pavés I, Ramos Ridao A (2007) Study of the energy potential of the biogas produced by an urban waste landfill in southern Spain. Renew Sust Energ Rev 11(5):909-922

202. Zeman $F$ (2010) Considering carbon capture and storage for energy generation from municipal solid waste. J Environ Eng 136(8):756-761

203. Zhang JH (2012) Characterization of a Rhizobium larrymoorei FJ exhibiting high level $\mathrm{Cr}(\mathrm{VI})$ reduction potential. Adv Mater Res 356-360:1009-1014

204. Zhao C, Zhao L, Chen X, Yin P, Yang Y (2012) A study on the collection efficiency of methane in municipal solid waste landfill. Huanjing Kexue Xuebao/Acta Scientiae Circumstantiae 32(4):954-959 
205. Zhao H, Wang J (2018) Chemical-looping combustion of plastic wastes for in situ inhibition of dioxins. Combustion and Flame 191:9-18

206. Zhong XP, Wang JJ, Zhao HW, Liu YS, Zeng H (2010) Investigation of heavy metals pollution in predominant plants around a municipal solid waste incineration plant: a case study in Shenzhen Qingshuihe MSWI plant. Acta Sci Nat Univ Pekin 46(4):674-680

207. Zhou H, Meng A, Long Y, Li Q, Zhang Y (2015) A review of dioxinrelated substances during municipal solid waste incineration. Waste Manag 36:106-118

208. Zubero MB, Eguiraun E, Aurrekoetxea JJ, Lertxundi A, Abad E, Parera J, Goñi-Irigoyen F, Ibarluzea J (2017) Changes in serum dioxin and PCB levels in residents around a municipal waste incinerator in Bilbao, Spain. Environ Res 156:738-746

Ready to submit your research? Choose BMC and benefit from:

- fast, convenient online submission

- thorough peer review by experienced researchers in your field

- rapid publication on acceptance

- support for research data, including large and complex data types

- gold Open Access which fosters wider collaboration and increased citations

- maximum visibility for your research: over $100 \mathrm{M}$ website views per year

At BMC, research is always in progress.

Learn more biomedcentral.com/submissions 